International Journal of Engineering \& Technology, 7 (2.29) (2018) $961-966$
International Journal of Engineering \& Technology
SPC
Website: www.sciencepubco.com/index.php/IJET
Research paper

\title{
Evaluation of Graduate Students Employability from Employer Perspective: Review of the Literature
}

\author{
Asma Ibrahim Gamer Eldeen ${ }^{1 *}$, Rabab Ali Abumalloh², Remya P George ${ }^{3}$, Danah A Aldossary ${ }^{4}$ \\ 1,2,3,4 Computer Department, Community College, University Of Dammam \\ *Corresponding Author E-Mail: Aieldeen@Uod.Edu.Sa
}

\begin{abstract}
Graduate employability is a critical issue in Higher Education. Employers are expecting not only the subject knowledge from the students to compete with the current industry demands, but also additional skills to face corporate battles and challenges. The aim of this research is to identify the skills demanded by the employers and to incorporate them in the learning outcomes of higher education. This research aims to review and analyses all the papers published from 2010 until now regarding the evaluation of graduate students from employers' perspectives. This subject has been rarely touched in literature and needs more focus regarding to its importance for both education institutions and employers. Papers were collected from different databases and carefully analyzed by the authors. Different classification methods were done. The results were analyzed. The results indicate that there is a gap between the learning outcome and the employability skills.
\end{abstract}

Keywords: Employability skills; Graduate performance; Graduate skills; Employers expectations; Emploers perspictives; Higher education; Prformance evaluation.

\section{Introduction}

Education is considered as a key of the success and the power in any nation. Education helps to develop the personality of the human and to communicate with others. The transformation process from a student to employee drives the social growth engine and develop the person socially and economically (Kulkarni et al. , 2014). Employability is the ability of an individual to gain employment appropriate to his/her educational standard (Dearing, 1997). Employability is not just about providing the student with the required attributes and techniques to get a respected job or to develop in a career. It can be described as a set of achievements and attributes that makes graduates more likely to gain employment and be successful in their chosen occupations, which benefits themselves, the workforce, the community and the economy (Yorke, M. 2006).

One of the basic tasks of education is to prepare and provide graduate students with the required skills to meet the needs of the labor market. There is a strong and direct relation between the education and the employment. This relation gained the researchers attention since 1960s. As a result, an increasing number of studies have been published to examine the relationship between education and employment(Cai,2012). The most focus on these studies was to observe the first employment after the graduation. Until 1990s, there was not a huge attention to the movement process from education to the career field. This change in the research can be referred to the use of the work success as an indicator to the quality of the education generally and higher education specifically (Teichler 2009). Since that, the needs of employment were taken into consideration from the universities, educational institutes and students in the teaching and learning processes. Unfortunately, the needs of the career fields are not so clear because of the rapid growth in the labour market. These challenges have induced the researchers to conduct more studies about the evaluation of the graduate from employment perspectives. The results of these studies were diverse and argumentative (Teichler ,2009). Employers are changing perceptions of workers with the same educational qualifications, these views vary according to the traditions, political factors and other factors.

\section{Research Methodology}

Enhancing graduate employability skills is the key task in higher education. Now a days employers are searching for graduates who are balanced with good academic credentials and possessing soft skills such as adaptability, communication, problem solving and interpersonal skills(1). This emphasis on the skills lead to the importance of recognizing employability skills and encorporating them to Higher Education (2). The employment skills expected from graduates vary by the employment sector, employer and countries.

This paper reviews the employability skills needed for various jobs in different countries based on the existing literature. In order to acheive the purpose of this study different well recoganized electronic libraries were searched such as: Acm Digital library, Science Direct, IEEE, Springer, Emerald and other resouces. The key words which ware used : Employability skills, Graduate performance, Graduate skills, Employers expectations, Emploers perspictives, Higher education and Prformance evaluation. Data collection started from November 2016 until February 2017. Papers were downloaded for the past 10 years and were divided among the authors to read and classify.Atotal of 85 papers were collected from the excitnig litreature. After that, appropriate information were extracted from the papers which 
include: paper name, journal name, publication year, aim of the study, research methodology, context and results. After the preliminary categorization processs the papers which were not relevant to the topic were excluded from the litreatre and we considred only 56 papers for further analysis. We identified that some of the collected papers were not within the scope of our research and hence didnt consider them for further analysis.29 papers were eliminated in the perliminary analysis. The papers resulted after the filtering process were classified based on: skills, industry and country. The collected data were analyzed to come up with the conclusion. The frame work of the research methodology we followed is presented in figure1.

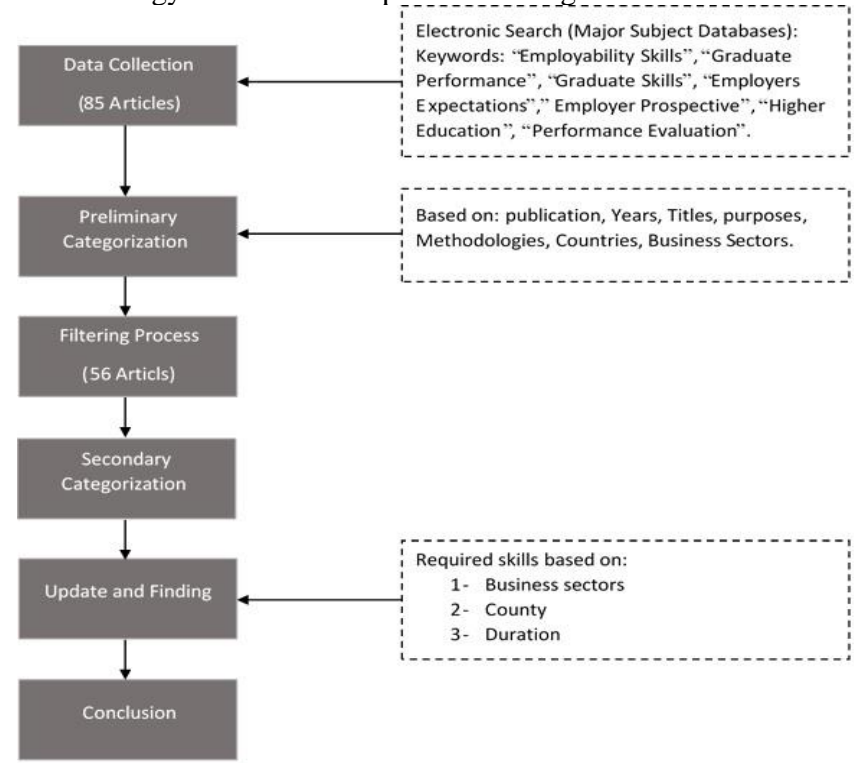

Fig. 1: Research Methodology

The collected papers were classified based on the industry. Table 1 illustrates the classification of papers based on industries

Table 1: Classificaion of papers based on indusries

\begin{tabular}{|l|l|c|}
\hline NO & \multicolumn{1}{|c|}{ Sector } & Total Papers \\
\hline $\mathbf{1}$ & Tourism/Hote/Hospitality & 13 \\
\hline $\mathbf{2}$ & Accounting & 11 \\
\hline $\mathbf{3}$ & Management & 2 \\
\hline $\mathbf{4}$ & Information and Communication Technology & 3 \\
\hline $\mathbf{5}$ & Manufacturing & 5 \\
\hline $\mathbf{6}$ & Construction & 16 \\
\hline $\mathbf{7}$ & General & 6 \\
\hline
\end{tabular}

\subsection{Tourism/Hospitality}

Tourism industry is one of the worldwide, fastest growing service oriented industry. The key challenge in the tourism industry is to manage with its international and interdisciplinary aspects. To meet with the demands of the tourism , people need to acquire competencies that enable them to cope with the changing circumstances of the business world(2).It seems that graduates are not well prepared and equipped with these skills to satisfy the requirements of employers.

The following studies tried to identify the skills necesary to function in the tourism industry. The Ciara et.al (3) conducted a study amongst employers and students in the Irish hotels and identified the following as the important competencies in this field: customer service, interpersonal skills, professionalism and maintaining ethical standards. The findings reveal the skill gaps exists between the graduate's skills and the expectations of the industry. Sarah et al (4), conducted a study amongst graduates and employers in Nairobi hotels to determine the expectations of hospitality industry. The major parameters considered for this study are the industry expectation, employee competence, quality and skill gap. The findings say that customer care, multi-skills, communication and level of service expected by the customers are the key skills expected in any hotel irrespective of its classification. Results identified some skill gap and suggest the correlation of industry and training providers to produce globally competitive employees. Besides the above, Faith et.al conducted a study focused on comparing employers' expectations of employee skills in the tourism industry and the skills acquired by learners in the Culture, Art, Tourism, Hospitality and Sport Skills Education Training Authorities' (CATHSSETA) (5). Results indicate that employers expect higher levels of competence than those which learners in the CATHSSETA program can deliver.

The skills expected by employers in various countries from the tourism graduates are listed in the below table. Even though many skills are identified for this industry, the most important skills expected from a graduate are Communication, Professional Knowledge, language and Management Skills.

Table 2: The skills expected by employers in various countries from the tourism graduates

\begin{tabular}{|l|l|}
\hline \multicolumn{1}{|c|}{ Country } & \multicolumn{1}{c|}{ Skills } \\
\hline Columbia & $\begin{array}{l}\text { Leadership, conceptual skills, communication, problem } \\
\text { solving, management skills }\end{array}$ \\
\hline Jordan & $\begin{array}{l}\text { Problem solving, technology, languages and culture } \\
\text { knowledge, and leadership skills }\end{array}$ \\
\hline Australia & $\begin{array}{l}\text { Academic Grades, Adaptability at Work, Computer Skills, } \\
\text { Critical Thinking, Decision Making, Events Management } \\
\text { Skill, Specific Knowledge, Communication, Organization- } \\
\text { al Ability, Problem Solving Skills, Relationship Manage- } \\
\text { ment Skills, Relevant Work Experience }\end{array}$ \\
\hline $\begin{array}{l}\text { South } \\
\text { Africa }\end{array}$ & $\begin{array}{l}\text { Professional knowledge, Operational and Communication } \\
\text { skill, IT, HRM, Numeric Skills, Analytical Skill, Team } \\
\text { work, Interpersonal Skills }\end{array}$ \\
\hline Philippines & $\begin{array}{l}\text { Critical Thinking, Problem Solving, Creativity, Passion, } \\
\text { Commitment, Teamwork }\end{array}$ \\
\hline Taiwan & $\begin{array}{l}\text { Leadership, Professional management, Technical skills, } \\
\text { professional skills classes, on-campus internship }\end{array}$ \\
\hline Spain & $\begin{array}{l}\text { Computer skills, responsibility at work, the ability to ac- } \\
\text { quire new knowledge, team working, communication } \\
\text { skills, Problem solving }\end{array}$ \\
\hline USA & $\begin{array}{l}\text { Communication, Conceptual Skills, Analytical Skills, } \\
\text { Team Work, Interpersonal }\end{array}$ \\
\hline Knowledge, Interpersonal Skills \\
\hline
\end{tabular}

\subsection{Accounting}

Accounting graduates should possess some desired skills to enable them as the providers of financial information in their profession (6). Recent studies criticize graduates that accounting education does not meet the requirement of the labour market and the needs of employers.

In 2015, Qasim conducted a study in Saudi Arabia to explore the skills expected by Saudi employers from accounts graduates. According to Qasim, accounting profession requires both technical and generic skills to effectively participate in their extended roles in the organizations (6). The findings suggests that critical reasoning and thinking, problem solving and decision analysis, oral and written communication, team working, business ethics, time management, negotiation, planning, computer knowledge and leadership are important for an account graduate.

Meanwhile, another study was conducted in Malaysia to identify the relationship between employers' satisfaction and employability skills possessed by UNITEN accounting graduates (7). The employability skills considered for this study are categorized into technical, functional, communication, organizational and business management skills. The results show that employers are satisfied with the employability skills possessed by the graduates(7).

However, employers have the assumption that all graduates would have good computing skills and with minimum training they can increase their computing ability (8).

The skills expected by employers in various countries from the accounting graduates are listed in the below table.

The skills expected by employers in various countries from the accounting graduates are listed in the below table. The most important skills expected from an account graduate are numerical and inter personal skills, MS Office and communication. 
Table 3: The skills expected by employers in various countries from the accounting graduates

\begin{tabular}{|l|l|}
\hline Country & Skills \\
\hline South Africa & Professional skills \\
\hline Australia & On-campus internship \\
\hline UK & Numerical Skills, transfer of knowledge and education \\
\hline Germany & Team Work \\
\hline Taiwan & Assessing the scale's psychometric properties. \\
\hline Malaysia & $\begin{array}{l}\text { Technical and Functional Skills, Communication Skills, } \\
\text { Organizational \& Management Skills }\end{array}$ \\
\hline New Zeland & $\begin{array}{l}\text { Accounting Skills, Technical \& Non-Technical Skills, } \\
\text { Interpersonal Skills, } \\
\text { Communication Skills, MS Office, Good Typing Speed }\end{array}$ \\
\hline Saudi Arabia & $\begin{array}{l}\text { Ethics, Leadership, Negotiation, Communication, Criti- } \\
\text { cal Reasoning \& Thinking, Problem \& Decision Analy- } \\
\text { sis, Team Working, Time Management, Computer Skills }\end{array}$ \\
\hline
\end{tabular}

\subsection{Management}

Today's employers are looking for graduates not only with specific knowledge but with the skills to act smart and handle the situations intelligently. Therefore, only graduates with better competencies can survive in the job market. Even though the graduates scored excellent result in their qualification, they are lagging in competency skills needed for the employment. Many studies were conducted to identify the competency skills needed for business graduates.

In 2012, S.Ken et al. conducted a research to explore the relationship between employers' perception about the important competencies in Malaysia banking industry and the actual performance of graduate students. The skill set considered for this study are resourcefulness, written and oral skills, honesty, diligence, knowledge-acquiring, teamwork, computer skills, valueimproving, adaptability, problem-solving and dependability. Findings reveal that graduates are well trained in their areas of specialization but unfortunately they lack the soft skills(1).

Another study is conducted in Kuwait to explore the level of importance of employability factors by employee's and academicians (9). Employability factors considered are the graduate's knowledge, soft skills, personal abilities and working with groups. The results revealed that the curriculum has to be developed to respond to the markets needs.

According to Herath \& Ranasinghe, ICT skills, English language proficiency and the applicability of practical knowledge are most important for business graduate (10).

The skills expected by employers in various countries from the management graduates are listed in the below table. The most important skills expected from a business graduate are Specific Knowledge, Management Skills, Diversity Awareness, Global Understanding Ability, Personal Traits and Computer Skills.

Table 4: The skills expected by employers in various countries from the management graduates.

\begin{tabular}{|c|l|}
\hline \multicolumn{2}{|c|}{ Skills Expected in Management Sector } \\
\hline Country & \multicolumn{1}{c|}{ Skills } \\
\hline Malaysia & $\begin{array}{l}\text { Communication, Specific Knowledge, Honesty, Adaptabil- } \\
\text { ity, Resourcefulness, Teamwork Ability, Diversity Aware- } \\
\text { ness Ability, Global Understanding Ability, Numerical } \\
\text { Skills, Problem-solving Skills, Computer Skills, Evalua- } \\
\text { tion Skills }\end{array}$ \\
\hline Bangladesh & $\begin{array}{l}\text { Management Skills (Planning), Technical Skills (Problem } \\
\text { Solving \& Analytical Skills) } \\
\text { Communication Skills, Personality Traits(Honesty, Posi- } \\
\text { tive Attitude) }\end{array}$ \\
\hline
\end{tabular}

\subsection{Information and Communication Technology}

Employability skills focus on graduates' abilities to adapt with the environment and make use of their skills to create resourceful educational outcomes which leads to employment(11). According to Saad and Majid, the most important skills demanded by the employers are problem-solving, tool handling competency, team working and presentation skills. The skills expected by employers in various countries from the ITC graduates are listed in the below table 5 ,
Table 5: The skills expected by employers in various countries from the ITC graduates

\begin{tabular}{|l|l|}
\hline \multicolumn{1}{|c|}{ Country } & \multicolumn{1}{c|}{ Skills } \\
\hline Malaysia & $\begin{array}{l}\text { Problem Solving, Tool Handling Competency, Presenta- } \\
\text { tion Skill, Team Working }\end{array}$ \\
\hline South Africa & $\begin{array}{l}\text { Personal Attributes, Creative \& Critical Thinking, Com- } \\
\text { munication Skills, Presentation Skills } \\
\text { Cultural Sensitivity, Self Management Ability, Team } \\
\text { Work, Problem Solving Skills }\end{array}$ \\
\hline
\end{tabular}

\subsection{Manufacturing}

According to Baqadir et al, Kingdom of Saudi Arabia has a serious shortage of skilled Saudi workers especially in the private sector(12). The findings highlight the skills gap centres on three factors: work ethics, specialized knowledge and generic skills. In 2015, (13), conducted a research among Russian manufacturing enterprises and finds that employers have lower understanding of their needs and skills requirements for the future. However the most important competences has to be considered for the curriculum developments are professional skills, technical skills and systemic thinking (13).

Table 6: The skills expected by employers in various countries from the Manufacturing Sector

\begin{tabular}{|l|l|}
\hline \multicolumn{1}{|c|}{ Country } & \multicolumn{1}{c|}{ Skills } \\
\hline $\begin{array}{l}\text { Saudi } \\
\text { Arabia }\end{array}$ & Work Ethics, Specialized Knowledge, Generic Skills \\
\hline Russia & $\begin{array}{l}\text { Systematic Thinking, Professional Skills, Communication } \\
\text { Skills, Adaptively }\end{array}$ \\
\hline USA & $\begin{array}{l}\text { Basic Skills, Computer Competency, Interpersonal Skills, } \\
\text { Problem Solving Skills. }\end{array}$ \\
\hline Malaysia & Teamwork skill and critical thinking \\
\hline
\end{tabular}

\subsection{Construction}

Many researches have been conducted in the domain of employability skills expected from graduates. Most of the available researches are either general or specific to some industry. In 2013, Philip Acheampong conducted a comparative study to identify the technical skills and abilities expected by the employers in the construction industries in Ghana and Nigeria. The expected technical skills for the construction industry are carpentry, plumbing, masonry, electrical, drafting, welding, and HVAC systems. Result indicated the lack of appropriate technical skills(14)

Table 7: The skills expected by employers in various countries from the Construction Sector

\begin{tabular}{|l|l|}
\hline \multicolumn{1}{|c|}{ Country } & \multicolumn{1}{c|}{ Skills } \\
\hline UK & $\begin{array}{l}\text { Time Management, team-working, Communication and } \\
\text { leadership, Interpersonal Skills }\end{array}$ \\
\hline USA & $\begin{array}{l}\text { Estimation, scheduling, plan reading, safety, Interpersonal } \\
\text { Skills }\end{array}$ \\
\hline Australia & $\begin{array}{l}\text { Practical Skills \& Knowledge, Pre-graduate work experi- } \\
\text { ence, time management }\end{array}$ \\
\hline Malaysia & $\begin{array}{l}\text { Responsibility, Positive Attitude, Team Work, Ability to } \\
\text { work under pressure, Time Management }\end{array}$ \\
\hline Sri Lanka & $\begin{array}{l}\text { engineering design and construction standards, working } \\
\text { attitude, technical and management skills }\end{array}$ \\
\hline Pakistan & $\begin{array}{l}\text { Knowledge of health \& safety regulations, Interpreting } \\
\text { contract documents, listening ability, Time Management, } \\
\text { Knowledge of building codes and regulations }\end{array}$ \\
\hline $\begin{array}{l}\text { Ghana \& } \\
\text { Nigeria }\end{array}$ & $\begin{array}{l}\text { Technical Skills, Business \& industry Knowledge, Intelli- } \\
\text { gence, Workplace Value }\end{array}$ \\
\hline Canada & $\begin{array}{l}\text { Construction acumen, project management and leadership, } \\
\text { business acumen, professionalism, and communication. }\end{array}$ \\
\hline Turkey & Knowledge, Interpersonal Skills \\
\hline
\end{tabular}

\subsection{General}

In the general employers' perceptions of the employability skills like teamworking, communication, leadership, critical thinking, problem solving from graduates, and there were some steps to 
the universities can apply such as planning to save effort and time of the students to develop them.

Table 9: General Skills Expected

\begin{tabular}{|c|c|}
\hline & Skill \\
\hline Basic Skills & Computer Skills \\
\hline & Work Ethics \\
\hline & MS Office \\
\hline Inter-personal Skills & Communication (Verbal, Non-Verbal, Listening) \\
\hline & Team Working \\
\hline & Time Management \\
\hline & Negotiation \\
\hline & Problem Solving \\
\hline & Conflict Resolution \\
\hline & Leadership \\
\hline & Adaptivity \\
\hline & Decision Making \\
\hline Intra-Personal Skills & Self Awareness \\
\hline & Self Regulation \\
\hline & Self Organized \\
\hline & Motivation \\
\hline & Honesty \\
\hline & Empathy \\
\hline & Discipline \\
\hline & Social Skills \\
\hline Specific Knowledge & Professional \\
\hline & Practical \\
\hline & Operational \\
\hline & On-Campus Internship \\
\hline
\end{tabular}

Table shows the journal we used in our paper

\begin{tabular}{|c|c|c|c|c|}
\hline 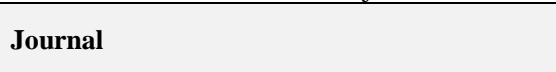 & $\begin{array}{l}\text { To- } \\
\text { tal }\end{array}$ & Yes & & \\
\hline $\begin{array}{l}\text { International Journal of Construction Education } \\
\text { and Research }\end{array}$ & 3 & $\begin{array}{l}20 \\
12 \\
\end{array}$ & $\begin{array}{l}20 \\
16 \\
\end{array}$ & $\begin{array}{l}20 \\
17 \\
\end{array}$ \\
\hline $\begin{array}{l}\text { International Journal of Construction Project } \\
\text { Management }\end{array}$ & 1 & $\begin{array}{l}20 \\
13\end{array}$ & & \\
\hline Medwell Journals & 1 & & $\begin{array}{l}20 \\
16 \\
\end{array}$ & \\
\hline Procedia Engineering & 1 & $\begin{array}{l}20 \\
14 \\
\end{array}$ & & \\
\hline European Journal of Engineering Education & 1 & $\begin{array}{l}20 \\
16 \\
\end{array}$ & & \\
\hline Recent Technological Advances in Education & 1 & & & \\
\hline Emerald & 1 & & & \\
\hline ACROM Conference & 1 & & & \\
\hline Online Journal & 1 & & & \\
\hline AOSIS Open Journal & 1 & $\begin{array}{l}20 \\
14 \\
\end{array}$ & & \\
\hline Journal of Hospitality Management \& Tourism & 3 & $\begin{array}{l}20 \\
12 \\
\end{array}$ & & \\
\hline Journal of European Industrial Training & 1 & $\begin{array}{l}20 \\
16 \\
\end{array}$ & & \\
\hline $\begin{array}{l}\text { Journal of Hospitality and Tourism Manage- } \\
\text { ment }\end{array}$ & 2 & $\begin{array}{l}20 \\
09 \\
\end{array}$ & & \\
\hline International Finance Corporation & 1 & $\begin{array}{l}20 \\
16 \\
\end{array}$ & & \\
\hline Journal of Hospitality \& Tourism Education & 2 & $\begin{array}{l}20 \\
14\end{array}$ & $\begin{array}{l}20 \\
15 \\
\end{array}$ & \\
\hline Journal of Business Studies Quarterly & 1 & $\begin{array}{l}20 \\
15 \\
\end{array}$ & & \\
\hline $\begin{array}{l}\text { Journal of Basic and Applied Scientific Re- } \\
\text { search }\end{array}$ & 1 & $\begin{array}{l}20 \\
15 \\
\end{array}$ & & \\
\hline Journal of Vocational Education \& Training & 1 & $\begin{array}{l}20 \\
11 \\
\end{array}$ & & \\
\hline Trends, Econimics AND Management & 1 & $\begin{array}{l}20 \\
16 \\
\end{array}$ & & \\
\hline Wiley online library & 1 & $\begin{array}{l}20 \\
16 \\
\end{array}$ & & \\
\hline Science Direct & 1 & $\begin{array}{l}20 \\
11\end{array}$ & & \\
\hline Global Journal of Engineering Education & 1 & $\begin{array}{l}20 \\
11\end{array}$ & & \\
\hline
\end{tabular}

\begin{tabular}{|c|c|c|c|}
\hline Journal of Information Systems Education & 1 & $\begin{array}{l}20 \\
17\end{array}$ & \\
\hline Jordan Journal of Business Administration & 1 & $\begin{array}{l}20 \\
15\end{array}$ & \\
\hline $\begin{array}{l}\text { South East Asia Journal of Contemporary } \\
\text { Business, Economics and Law }\end{array}$ & 1 & $\begin{array}{l}20 \\
15\end{array}$ & \\
\hline Journal of Information Technology Education & 1 & $\begin{array}{l}20 \\
11\end{array}$ & \\
\hline $\begin{array}{l}\text { e-Journal of Business Education \& Scholarship } \\
\text { of Teaching }\end{array}$ & 2 & $\begin{array}{l}20 \\
15\end{array}$ & $\begin{array}{l}20 \\
16\end{array}$ \\
\hline $\begin{array}{l}\text { The International Business \& Economics Re- } \\
\text { search Journal }\end{array}$ & 1 & $\begin{array}{l}20 \\
13\end{array}$ & \\
\hline Academy of Educational Leadership Journal & 1 & $\begin{array}{l}20 \\
15\end{array}$ & \\
\hline Education + Training & 1 & $\begin{array}{l}20 \\
15\end{array}$ & \\
\hline Accounting Education & 1 & $\begin{array}{l}20 \\
04\end{array}$ & \\
\hline Higher Education Research \& Development & 1 & $\begin{array}{l}19 \\
99\end{array}$ & \\
\hline Public Administration Quarterly & 1 & $\begin{array}{l}20 \\
16\end{array}$ & \\
\hline South Asian Journal of Management & 1 & $\begin{array}{l}20 \\
11\end{array}$ & \\
\hline World Review of Business Research & 1 & $\begin{array}{l}20 \\
12\end{array}$ & \\
\hline $\begin{array}{l}\text { 19th International Conference on Industrial } \\
\text { Engineering \& Engineering Management }\end{array}$ & 1 & $\begin{array}{l}20 \\
13\end{array}$ & \\
\hline Journal of Career and Technical Education & 1 & $\begin{array}{l}20 \\
11\end{array}$ & \\
\hline Asian Social Science & 1 & $\begin{array}{l}20 \\
12\end{array}$ & \\
\hline Creative Associates International & 1 & $\begin{array}{l}20 \\
15\end{array}$ & \\
\hline Edge Foundation & 1 & $\begin{array}{l}20 \\
11\end{array}$ & \\
\hline $\begin{array}{l}\text { Graduate Careers Australia Ltd (trading as } \\
\text { Graduate Careers Australia) }\end{array}$ & 1 & $\begin{array}{l}20 \\
14\end{array}$ & \\
\hline
\end{tabular}

Table and chart show the number of journal we collected in each year: Table show that we constraint on our paper in the most recent publication

\begin{tabular}{|c|c|}
\hline Years & Number of papers \\
\hline 1999 & 1 \\
\hline 2000 & 0 \\
\hline 2001 & 0 \\
\hline 2002 & 0 \\
\hline 2003 & 0 \\
\hline 2004 & 1 \\
\hline 2005 & 0 \\
\hline 2006 & 1 \\
\hline 2007 & 0 \\
\hline 2008 & 0 \\
\hline 2009 & 3 \\
\hline 2010 & 0 \\
\hline 2011 & 9 \\
\hline 2012 & 7 \\
\hline 2013 & 4 \\
\hline 2014 & 8 \\
\hline 2015 & 10 \\
\hline 2016 & 8 \\
\hline 2017 & 1 \\
\hline
\end{tabular}




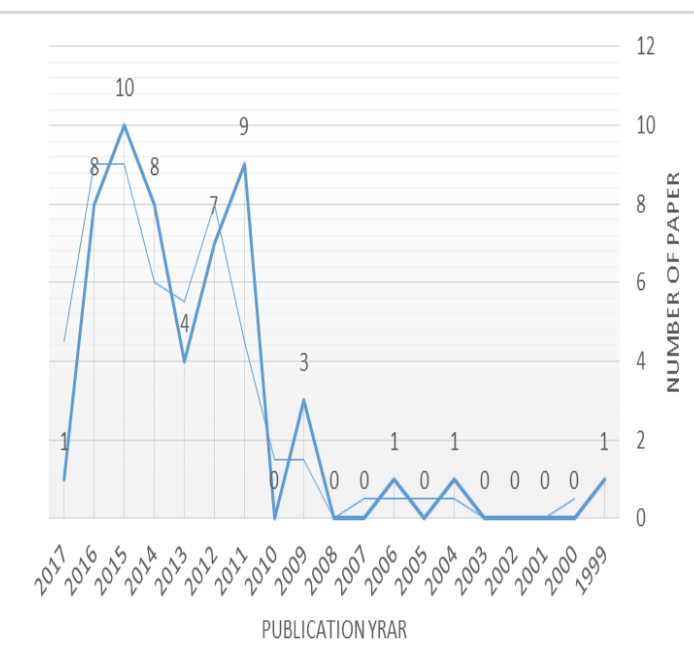

\section{Results and findings}

The collected papers were classified based on the industry, country and the expected skills from the graduate students. Findings are really interesting. Results indicate that employment sectors expect a set of general skills as well as specific knowledge from every employee. Based on the findings, we have classified these skills into 4 categories such as Specific Knowledge, Basic Skills, Inter-personal, and Intra-Personal Skills. .

Table 9: General Skills Expected

\begin{tabular}{|c|c|}
\hline \multicolumn{2}{|c|}{$\begin{array}{r}\text { General Skills Expected } \\
\end{array}$} \\
\hline \multirow{3}{*}{ Basic Skills } & Computer Skills \\
\hline & Work Ethics \\
\hline & MS Office \\
\hline \multirow{9}{*}{ Inter-personal Skills } & Communication (Verbal, Non-Verbal, Listening) \\
\hline & Team Working \\
\hline & Time Management \\
\hline & Negotiation \\
\hline & Problem Solving \\
\hline & Conflict Resolution \\
\hline & Leadership \\
\hline & Adaptivity \\
\hline & Decision Making \\
\hline \multirow{8}{*}{ Intra-Personal Skills } & Self Awareness \\
\hline & Self Regulation \\
\hline & Self Organized \\
\hline & Motivation \\
\hline & Honesty \\
\hline & Empathy \\
\hline & Discipline \\
\hline & Social Skills \\
\hline \multirow{4}{*}{ Specific Knowledge } & Professional \\
\hline & Practical \\
\hline & Operational \\
\hline & On-Campus Internship \\
\hline
\end{tabular}

\subsection{Construction}

The construction industry plays a major role in the national economy of every country. But compare to other industries construction industry is little bit complex due to its applied nature. So it can never be confined only to classroom. Rather students should be exposed to the industry. The challenge in construction industry is to upgrade oneself with the constantly evolving technologies, machineries and tools. Due to this the industry expectations from the graduates are continually changing. Existing literature reveals that there are many studies conducted to identify the gap between the expectations of the employers and the perceptions of the students about construction industry in terms of knowledge base and skills essential to work efficiently in the construction industry.
According to Shyamalee, a fresh engineering graduate should have understanding about engineering design and construction standards, working attitude,technical and management skills, personal attitude and Engineering Knowledge(15). Similarly Construction knowledge such as estimation, scheduling, plan reading, safety, etc are also very important for graduates (16). Sedighi conducted a study in Australia to indentify the graduate's employer preferences and the factors affecting them. Since the risk factors in construction industry are more comparing to many other industries, graduates are expecting a safe work place, diversity, equal opportunities, work-life balance, gender equity, a workplace with training programs, training in how to use new technologies, high income and Flexible hours. (17). Similarly Saqib identified five most important skills desirable in a construction management firm including knowledge of health and safety regulations, interpreting contract documents, listening ability/ giving attention to details, knowledge of building codes and regulations, and time management.(18). (19) reveals that the USA construction industry is looking for graduates who have a deep conceptual knowledge of BIM rather the skilled on using Building Information Modelling software.

(20) used text mining to identify the employer preferences by analyzing the employment data posted on the job portals. The result indicates that the major skills required by all jobs are communication, degree, Team work and MS Office(20). Olawale (2015) also noted that team-working, Communication and leadership are the most sought skills expected by the employers(21).Rohani believes that responsibility, positive attitude and team work are the 3 most important attribute for architecture industry (22). Where as Practical building knowledge and interpersonal skills along with time management are also importance for construction management graduates (23).

The skills expected by construction employers in various countries $\mathrm{s}$ are listed in the below table. The most important skills identified are the Specific knowledge to the industry, Time Management and interpersonal and intra personal skills.

\section{References}

[1] Ken S, Ting T, Ying CY. Business Graduates' Competencies in the Eyes of Employers : An Exploratory Study in Malaysia. World Rev Bus Res. 2012;2(2):176-90.

[2] Markes I. A review of literature on employability skill needs in engineering. Eur J Eng Educ. 2006;31(6):637-50.

[3] Nolan C, Conway E, Farrell T, Monks K. Competency needs in Irish hotels: Employer and graduate perspectives. J Eur Ind Train. 2010;34(5):432-54.

[4] Kamau SW, Waudo J. Hospitality industry employer's expectation of employees' competences in Nairobi Hotels. J Hosp Manag Tour. 2012;3(4):55-63.

[5] Zwane FN, du Plessis L, Slabbert E. Analysing employers' expectations of employee skills in the South African tourism industry. South African J Hum Resour Manag. 2014;12(1):1-9.

[6] Zureigat QM. Accounting Graduates Skills and Employers 'Needs : The Saudi Case. Jordan J Bus Adm. 2015;11(1):227-38.

[7] Shamsuddin A, Tenaga U. Employers â $€^{\mathrm{TM}}$ Level of Satisfaction Towards Accounting Graduates. South East Asia J Contemp Business, Econ Law. 2016;7(1):22-31.

[8] Gibbs S, Steel G, Kuiper A. Expectations of Competency: The Mismatch between Employers ' and Graduates ' Views of EndUser Computing Skills Requirements in the Workplace. J Inf Technol Educ. 2011;10:371-82.

[9] Abdullah A, Naser K, Saeid M. Factors Impact Business Graduates Employability: Evidence from Academicians and Employers in Kuwait. Int J Acad Res Econ Manag Sci. 2014;3(4):150-75.

[10]Herath HMTS, Ranasinghe A. Labour Market Prospects for Business Graduates in Sri Lanka. Int $\mathbf{J}$ Soc Sci Humanit. 2011;1(1):26-30

[11]Saad MSM, Majid IA. Employers' perceptions of important employability skills required from Malaysian engineering and information and communication technology (ICT) graduates. Glob J Eng Educ. 2014;16(3):110-5. 
[12] Baqadir A, Patrick F, Burns G. Addressing the skills gap in Saudi Arabia: does vocational education address the needs of private sector employers? J Vocat Educ Train. 2011;63(4):551-61.

[13] Svirina A, Suslova O, Dashina E. Preffered Competence Structure of University Graduates: Russian Employers ' Point of View. 2016;8527(1):40-7.

[14] by. 2013;(May).

[15] Shyamalee MMG V, Wickramasinghe WMVSK, Dissanayake S. Employability Skills Expected from Fresh Civil Engineering Graduates. Recent Technol Adv Educ. 2010;54-9.

[16] Bhattacharjee S, Ghosh S, Young-Corbett DE, Fiori CM. Comparison of Industry Expectations and Student Perceptions of Knowledge and Skills Required for Construction Career Success. Int J Constr Educ Res. 2013;9(1):19-38.

[17] Sedighi F, Loosemore M. Defining employers-of-choice in the construction industry from a graduate perspective.

[18] Saqib M, Student PD. Desirable Attributes and Skills for Graduating Construction Management Students. Methodology. 2001;

[19] Taiebat M, Ku K. Industry â€ $€^{\mathrm{TM}} \mathrm{s}$ Expectations of Construction School Graduates â€ $€^{\mathrm{TM}}$ BIM Skills. 2009;8.

[20] Gao L, Eldin N. Employers' expectations: A probabilistic text mining model. Procedia Eng. 2014;85:175-82.

[21] Olawale Y. the Employability Skills Provision Within a Construction Project Management Degree Programme. 2015;(September):959-68.

[22] Attributes of Graduate Architects - Industry perspective.pdf.

[23] Love PED, Haynes NS, Sohal a S, Chan a PC, Tam CM. Key Construction Management Skills for Future Success. 2002;(May 2017). 